\title{
INFLUENCE OF MELODY FM NIGERIA GO BETTER, A PIDGIN ENGLISH RADIO PROGRAMME IN CREATING DEVELOPMENT AWARENESS IN WARRI, NIGERIA
}

\author{
Ubini Caroline \\ Department of Mass Communication \\ Delta State University, Abraka \\ carolineubini@gmail.com \\ Majority Oji \\ Department of Mass Communication \\ Delta State University, Abraka \\ ojimajority@delsu.edu.ng
}

\begin{abstract}
The study investigates how radio has been used as a carrier of development information to create awareness on development issues among people of Warri, Nigeria. The study builds on what researchers have recognized as the strength of radio in spurring peoples' interest and participation in development matters. The study adopts the crosssectional research method to sample the views of 240 respondents drawn from Warri population. The graduated data derived from a Likert scale were statistically analysed using percentages. The findings reaffirmed the rationalized position of scholars on the use of radio in the direction of development. The sustainability of the programme and the quest for future capable hands to continue to run the programme however remain a worry to the people and are recommended for action.
\end{abstract}

Keywords: Radio; Development; Awareness; Broadcasting;Warri;

\section{INTRODUCTION}

Most constitutions in the world guarantee freedom of speech. It is constitutional human rights in most countries with laissez-faire attitude to governance. Section 39 (1) of the Constitution of Nigeria defends freedom of expression (Act No. 24). However, in most climes free speech is often clothed in controversy. Wihl (2018) and Harel (2011) clear the controversy line by stating that different societies grant different protection to freedom of expression. The different status accorded freedom of expression in different countries open the floodgate for diverse legal interpretations and other forms of political insinuations. Carlsson and Pöyhtäri (2017) noticed in their study on freedom of expression that writers and different people who try to practice their entitlement to the right of freedom of expression are regularly the target of assaults.

The broadcast media have certain unique qualities that make different governments in the world to want to oversee its operations. The broadcast media do not only break the distance barrier, that is, its messages reach audience immediately; it equally breaks the illiteracy barrier thereby making everyone who understands the language in which a programme is broadcast to participate in it. What this means is that the broadcast media can be used as a tool to galvanize people into immediate action. Governments across the globe are very wary of this 'special'quality of the broadcast medium. This explains the reason different governments are interested in the management of the broadcast media where radio is a family member. 
DOI: doi.org/10.47851/naujocommed.v2i1.111

Pidgin English, it is a grammatically simplified form of communication that is very useful to a people of a mixed linguistic background. Pidgin English is the main language in Warri where the Nigeria Go Better programme is broadcast. Thus, to add the advantages of radio to that which Pidgin English possesses would be a big plus for a radio programme to make an impact.

Nigeria Go better is a radio magazine programme that has been running on Melody FM, an arm of Delta Broadcasting Service (DBS) Warri for over ten years. Nigeria Go better is an hour programme aired on Saturdays with discussions, interviews, talk, drama, reviews, news and music segments that are selected for broadcast. The main focus of the programme is development. The programme was originally known as Na So We See Am. The popularity of the programme among the people of Warri informed the change of title to Nigeria Go Better in 2015 to better reflect its development drive. The principal characters behind the programme are 'Kedekede', 'Countryman,' 'Wakawaka,' and 'Madam Better.' These are the characters that constitute the panel to discuss emerging issues from the different segments.

Warri constitutes the study area. It is a bustling 'oil city' where the use of Pidgin English is very common. The use of Urhobo, Ijaw and Itsekiri, the local languages of the indigenes not withstanding, the use of Pidgin English pervades the economic, political and socio-cultural lives of the people. Shnukal and Marchese (1983) found in their study that Pidgin English is used in class room teaching in the city. Motanya (2017) contended that Pidgin English remains the most used language in Nigeria but unfortunately has no official backing.

In Nigeria Go Better, the interface of Pidgin English and the freedom to express one's opinion provides that needed environment to push the agenda for development. However, the intrigues involved in using a high level of communication engineering to drive development agenda through the propagation of free speech in Nigeria Go Better and, be able to break the haze surrounding governments' intemperate attitude towards free speech is worth studying.

\section{STATEMENT OF THE PROBLEM}

The programme Nigeria Go better is a Pidgin English magazine programme broadcast on Melody FM on 88.6 frequency. It is an extensive broadcast plan of action for reforms in development. The programme is broadcast in a language laced with opinion. It makes it possible for the programme discussants and the people of the locality who contribute to discussions on the programme to freely express their views on development matters. The programme, Nigeria Go Better, has focused on development issues such as bad roads, waste disposal problems, electricity supply issues, activities of government agencies, corruption in all its ramifications, poverty and inequalities in the society and many more interesting issues. However, considering the silent restraints imposed on freedom of expression as it pertains to exposé on government officials' wrong doings and other government's activities, the fear is expressed if the programme totally mirrors society expectations for the practice of freedom of expression. This brings about the question: How do the people of Warri evaluate the influence of Nigeria Go Better, a Pidgin English programme,on development in Warri.

\section{OBJECTIVES OF THE STUDY}

The study intends among other things:

I. To find out if the people of Warri are aware of Nigeria Go Better Pidgin English 
Volume 2 Number 1 Jan-Mar Issue

DOI: doi.org/10.47851/naujocommed.v2i1.111

programme.

II. To ascertain the level of knowledge of Nigeria Go Better Pidgin English programe among the people of Warri.

III. To find out the level of participation in the Nigeria Go Better Pidgin English programme among the people of Warri.

IV. To determine if the Pidgin English programme, Nigeria Go Better has helped to create awareness on development issues among the people of Warri.

\section{RESEARCH QUESTIONS}

The following research questions were asked to guide the study:

1. What is the awareness level of Nigeria Go Better Pidgin English programme among the people in Warri?

2. What is the level of knowledge of Nigeria Go Better Pidgin English programme among the people of Warri?

3. What is the level of participation of the people in Warri in the Nigeria Go Better Pidgin English programme?

4. Has the Pidgin English programme Nigeria Go Better been able to create awareness on development issues among the people of Warri?

\section{LITERATURE REVIEW}

To allow people to hold different shades of opinion and openly share ideas on public issues without intimidation or fear of legal reprisals from government or any organ of government, such a society can be described as free and exist under a free reign of freedom of expression. In such climes people are free to associate and share views on matters of governance, economy, social engagements, and other societal issues.

Over the years, the free rights enumerated above have been subjected to harrowing interpretations to suit the whims and fancies of rulers. Sometimes, obnoxious laws are enacted, and are intentionally interpreted to infringe upon the freedom of expression. The enactment of Cybercrime Act in Nigeria in 2015 led to the undue interference on the rights of individuals and their arbitrary detention (Rights Watch, 2017).

Rights Watch (2017) reported cases of the arbitrary arrest of journalists working with Premium Times Online. The human rights group also reported the arrest of IbraheemaYakubu, a reporter with a radio station that broadcast Hausa service and that of Danjuma Katsina, a journalist who was arrested and detained in katsina.

Radio allows majority of the people that tune to it to participate in information sharing because its messages are coded to break language barriers in the communication process. In this regard, radio helps to bring different people together to articulate their views in a common forum.Katunzi (2012) established through a study of Orkonerei Radio Service FM 
DOI: doi.org/10.47851/naujocommed.v2i1.111

(ORS FM) that radio effectively delivers on people's participation and access to development programmes.

To add to Katunzi findings, Rahman,Ullah and Khan (2017) surveyed seven radio stations and found that radio is very useful for educational purposes and contributes positively in helping people through the process of decision making that is based on facts. Mhagama (2015) reported how effective media participation through radio helped the people of Malawi to be well informed and made it possible for them to participate in development initiatives.

For Faisal and Alhassan (2018) in their study of Radio Gaakii's, Ghana, the authors found there was a gap that should be filled. The key information they gave was that community members do not go beyond the listening stages of the programme. To remedy the situation, the authors recommended a Radio Gaakii Listening Club to make it possible for the people to hook up with development issues canvassed on radio. In Mohammed (2013) study on "Challenges and Opportunities in the Use of Radio Broadcast for Development in Ethiopia," the problem angle is different. The author found that although radio appeared to be the most preferred means of communication in Ethiopia, the possession of radio receivers in that county remain poor. He cautioned that the development constitutes impediments to what radio can be used to achieve for an illiterate farmers' population.

For Mann (2000) Pidgin English has been applied successfully in mobilization programmes. The researcher's finding was skewed to the areas of health and social engagements. In Nigeria, Pidgin English is the latest rave in radio broadcasting (Wazobia,2012). Akoh and Jagun (2012) opine that Pidgin English radio is now very popular in Nigeria. Ibukun (2010), Asokan (2011) and Mark (2012) lend support to Akoh and Jagun by stating that Pidgin English radio has attracted attention from the international media.

Ndolo (2017) citing Ayeni (1987) discussed the use of Pidgin English as one of the most effective means of communication in Nigeria. According to the scholar, it helps to bridge communication between and among the different ethnic groups in the country. Osoba (2014) in support of Ndolo's views expressed the fact the use of Pidgin English is now prevalent among Nigerians. He noted that Pidgin English is simple and acquired without difficulty. These traits are what that make it easily accessible to a multilingual society like Nigeria.

\section{THEORETICAL REVIEW}

Theoretical postulations in mass communication has over the years moved from what is believed to be hypnotic impact of mass media messages to a more tolerable zone where the individual is recognized as a rational being. The Uses and gratification theory actually concedes to audience members the right to make the choice of medium for his needs gratifications. This means the media use of an active/rational audience is goal oriented. However, there is a missing gap here. The audience will have no choice to make if the information they seek is not made available to them.

Thus, the Agenda Setting Theory would be applied in this study. The unique core assumptions of the theory render it useful in the realms of public opinion research. The theory postulates that though the media does not totally reflect reality, it filters and shapes what is presented to the audience to help the rational being in his thinking process (McQuail, 2010; Weaver, 2007). Also, the issues in the media are presented in order of importance to help the audience decipher what is important to think about (McCombs and Reynolds, 2002) 
The application of the agenda setting theory to this study is hinged on the fact that the programme Nigeria Go Betters erves as an avenue to focus on public issues. Thus, debates, interviews and discussions in Nigeria Go Better are used to set development agenda for the public, government and its officials to explore. It is an attempt to replicate the empirical exploration of McCombs and Shaw in the 1968 United States elections in a broadcast/developmental study. It would be good to see how the Nigeria Go Better programme has influenced development in Warri.

The study draws on the immeasurable potential of the media to influence public opinion. Thus, through the Nigeria Go Better programme, issues of national public importance are mirrored for everyone to see and whatever that is the fall-out of the debates are expected to galvanized public opinion to help shape how government is run, how development programmes are executed or in some instances how societal relationships are established and oiled.

The ideas shared in second level agenda setting may not be directly applicable to this study (McCombs, Shaw and Weaver, 2014). However, the overall outlook of the study, especially in the findings shall help in the understanding of the concept of the Need For Orientation (NFO). The Need For Orientation is the most conspicuous unforeseen condition for agendasetting impacts. It gives a mental clarification to why individuals participate in data chasing and why some people are susceptible to agenda-setting impacts and others are not motivated. Matthes (2008) explained NFO in relationship to development and noted that it provides important insight into specific development attributes that serve as orienting cues to individuals understanding of mass media messages. It is known that NFO properties define how much information is consumed in a message by individuals in needs. It can be deduced that the more the impediments to the need for a message or information, the less influence such a message will have and, consequently the carrying programme.

\section{METHODS}

The study adopts the cross sectional design utilizing the survey approach as it is useful in data information search. In the absence of data to determine audience participation in broadcast programmes in Nigeria, the study draws on the general population of Warri and the area of coverage of the programme and not on the audience of Nigeria Go Better. Warri occupies what is known today as Warri South-West Local Government Area. The population of Warri in the 2006 census was 311,000 (NPC, 2006). According to Falade (2019) and George, et al., (2004) when the original population is unavailable, population projection using growth rate has proven to be a good alternative to actual population.Thus, projected to 2021 using a growth of $2.58 \%$, the population of Warri now stands at 458, 377. From the result of Little

\section{Dubb Table Size}

formular $\underline{\mathrm{N}=\mathrm{X}^{2 *} \mathrm{~N} * \mathrm{P}(1-\mathrm{P})}$

$\left(\mathrm{ME}^{2 *}(\mathrm{~N}-1)\right)+\left(\mathrm{x}^{2 *} \mathrm{P}(1-\mathrm{P})\right)$ for Warri population fragemented in Taro Yemeni'

$\mathrm{n}=$

$$
1+\mathrm{N}^{*}\left(\mathrm{e}^{2}\right)
$$

where $\mathrm{n}$ is sample size, $\mathrm{N}$, the population size and e, the acceptable sampling error a sample size of 240 was picked from the population with $5.0 \%$ margin of error. The study ensures the smallest part of the population has an equal chance of being selected through random sampling of the population. The views of respondents were sampled across the different demographic variables of age, gender, occupation and education in th 
DOI: $\underline{\text { doi.org/10.47851/naujocommed.v2i1.111 }}$

area of coverage of the programme. The instrument for data collection was a Likert Scale structured questionnaire. The graduated data were statistically analyzed using percentages.

\section{DATA PRESENTATION, ANALYSIS AND DISCUSSION OF FINDINGS Questionnaire Return Rate}

A total of 240 copies questionnaire were sent out. Out of this number 228 copies of questionnaire were returned, making for $95 \%$ return rate. The return rate is good enough for the study.

Table 1: Demographic Data

\begin{tabular}{lll}
\hline Sex & Frequency & Percentage $(\%)$ \\
\hline Male & 120 & 53 \\
Female & 108 & 47 \\
Total & 228 & 100 \\
Age & Frequency & Percentage $(\%)$ \\
$18-40$ & 133 & 58 \\
$41-$ above & 95 & 42 \\
Total & 228 & 100 \\
Occupation & Frequency & Percentage $(\%)$ \\
Unemployed & 53 & 23 \\
Civil Servants & 73 & 32 \\
Private Sector & 102 & 45 \\
Total & 228 & 100 \\
Educational Level & Frequency & Percentage $(\%)$ \\
Primary & 73 & 32 \\
Secondary & 92 & 40 \\
Tertiary & 63 & 28 \\
Total & 228 & 100 \\
\hline
\end{tabular}

From table I above, there are more males (53\%) than females (47) percent that responded to the questions. The majority of the respondents (58\%) are within the age range of 18 to 40 years. The others age group who are 41years and above constitute $(42 \%)$. This corresponds with age distribution pattern in Nigeria population where the greater percentage of the population is with the age youths age bracket.(Statista(n.d)).For occupation, more of the respondents with $45 \%$ are in the private sector compared to civil servants with $(32 \%)$ and the unemployed with $23 \%$. In the educational category, there are more of Secondary School Certificate holders that constitute $(40 \%)$ of the population compared to Primary School with $(32 \%)$ and Tertiary (28\%)

Table 2: Awareness of Nigeria Go BetterProgramme

\begin{tabular}{llcc}
\hline Numerical Value & Response Categories & Frequency & Percentage\% \\
\hline 1. & Strongly Agree & 45 & 20 \\
\hline & & \\
& &
\end{tabular}


NNAMDI AZIKIWE UNIVERSITY JOU

Journal OF COMMUNICATION HND MEDU STUDIES

Volume 2 Number 1 Jan-Mar Issue

\begin{tabular}{llrr}
\hline 2. & Agree & 108 & 47 \\
3. & Undecided & 13 & 6 \\
4. & Disagree & 43 & 19 \\
5. & Strongly Disagree & 19 & 8 \\
Total & & 228 & 100 \\
\hline
\end{tabular}

Source: Researchers' field survey, 2019

Table 2 showed that about two third (67\%) of respondents have awareness of the programme. This is against (27\%) of the respondents who do not have awareness of the programme. About $6 \%$ were undecided on the issue of awareness of the programme. The outcome demonstrates that the citizens of Warri and its environs are well-versed in the program. They know what time the program will be transmitted, which channel to tune to, and the signal is good enough for them to listen to the station at that hour.

Table 3: Knowledge of Nigeria Go BetterProgramme

\begin{tabular}{llcc}
\hline Numerical Value & Response Categories & Frequency & Percentage\% \\
\hline 1 & Strongly Agree & 30 & 20 \\
2 & Agree & 87 & 57 \\
3 & Undecided & - & 0 \\
4 & Disagree & 26 & 17 \\
5 & Strongly Disagree & 10 & 6 \\
Total & & 153 & 100 \\
\hline
\end{tabular}

Source: Researchers' field survey, 2019

From table 3,77\% which is about two-third of the respondents who said they are aware of the programme also acknowledge having knowledge of the programme. This is against $33 \%$ of the respondents who said they do not know what theprogramme is about but have heard it on radio. This demonstrates that the people are well-informed about the programmes. Its growth strategy, anti-corruption stance, and overall goal, which is to make Warri a better place.

Table 4: Participation in Nigeria Go BetterProgramme

\begin{tabular}{clcc}
\hline Numerical Value & Response Categories & Frequency & Percentage \\
\hline 1 & Strongly Agree & 21 & 18 \\
2 & Agree & 90 & 77 \\
3 & Undecided & - & 0 \\
4 & Disagree & 5 & 4 \\
5 & Strongly Disagree & 1 & 1 \\
Total & & 117 & 100 \\
\hline
\end{tabular}

Source: Researchers' field survey, 2019

From table 4, 95\% which is $5 \%$ away from the total number of the respondents who have knowledge of the programme said they also participate in the programme. This is against 5\% of the respondents who said they do not know what the programme is about but have heard it on radio. The high participation level of those who have knowledge of the programme is influenced by the activities of the crew members of the Nigeria Go Better. The members in their individual' roles engage the public in investigations, interviews and other activities that are either reported or broadcast in the course of the Saturday broadcast of the programme 
(Researcher's Field Survey (2021). The respondents mentioned that they are very active participants in the programme.

Table 5: Awareness on development issues in Warri environs

\begin{tabular}{clcc}
\hline Numerical Value & Response Categories & Frequency & Percentage \\
\hline 1 & Strongly Agree & 49 & 44 \\
2 & Agree & 59 & 53 \\
3 & Undecided & - & - \\
4 & Disagree & 3 & 3 \\
5 & Strongly Disagree & - & - \\
Total & & 111 & 100 \\
\hline
\end{tabular}

Source: Researchers' field survey, 2019

From table 5, 97\% which is just short of $3 \%$ of the respondents that have knowledge of Nigeria Go Better programme and have participated in it. According to those who have participated in the Nigeria Go Better initiative, the programme has raised awareness about development problems in the Warri region. The discovery supports the reason why the programme's name was changed from $\mathrm{Na}$ So We See Am to Nigeria Go Better, which has a growth tinge to it because of its emphasis on development issues and popularity among Warri residents.

\section{DISCUSSION OF FINDINGS}

Respondents across different works of life responded to the quest to ascertain how the programme Nigeria Go Better has faired among the people of Warri and to see if the programme has in any way impacted on people's awareness on development issues.

The study found that people of Warri are aware of the programme in the ratio of $67 \%$ for those who are aware to $27 \%$ for those are not aware of the programme. The high awareness level gives credence to the popularity of the programme. This also goes to show that the signal of the broadcasting station is strong and ensure reception at the receiving end. Poor signal reception would affect every other thing about a programme to distort or deprive it from achieving its intended goal. Mtega (2018) actually wrapped it up by stating that accessibility of radio and television signals contribute in the propagation of information needed for agricultural knowledge and eventual acquisition of such agricultural knowledge.

The study also found that the people of the locality have knowledge of the programme. This is very important as having knowledge of a programme provides the recipient of a piece of information to know what the programme is about and be able to contribute meaningfully to instigated action. This is in line with Seidu, Andani and Abdul-Malik (2011) finding that Simli Radio helped the people of Savelugu-Nanton and Tolon-Kumbungu areas of Ghana to improve their livelihood. 
DOI: doi.org/10.47851/naujocommed.v2i1.111

The level of participation in the programme Nigeria Go Better was also found to be very good. This is against the run of events where the feedback is very slow in the traditional media. However, participation in the programme was not only based on direct participation in the programme. The Nigeria Go Better crew members constantly engaged the people in interviews, investigations and also in bringing the people on through vox pops. The case of radio Gaaki in Ghana comes handy here. The programme initiates and ensures its success through community participation to effect development (Faisal and Alhassan, 2018). For Choudhury (2011), the people participating are directly in the development programme such as the family welfare programme in India propagated through the radio.

The programme has also succeeded in creating awareness on development issues in the Warri environ. Nwagbara and Nwagbara (2017) were able to establish how radio broadcast was able to create awareness on climate change among farmers in Abia state, Nigeria.Sanni and Ojewale (2013) were also able to establish "Media influence in awareness creation for government development projects in Lagos State, Nigeria" in their study. The Nigeria Go Better programme success in creating awareness on development issues no doubts contributes to the overall development of Warri environs.

\section{CONCLUSION}

The study investigates whether the programme Nigeria Go better achieved its goals of creating awareness and knowledge on development issues in Warri environs. The findings in this study also tally with results in similar studies that have been carried out using radio as a carrier of development messages. The findings are in accord with Fraser and RestrepoEstrada (2002) and Shinkhede (2019) that projected radio as a very essential component that can help trigger social change. The scholars noted, just as implied in this study, that aired complaints, discussions, suggestions, and recommendations from programmes like Nigeria Go Better can help force government and other authorities to re-engineer governance to encompass universally acceptable standards.

\section{REFERENCES}

Asokan, S. (2011,June). Nigerian Pidgin radio station takes off. Global Post. Available on http://www.globalpost.com/dispatch/news/regions/africa/nigeria/110623/nigeriaspidgin-radio- wazobia

Ayeni, D. (1987). Personal Communication as Assistant Director Education, Federal Radio Corporation of Nigeria (FRCN), Lagos Zone), May 12

Carlsson, U., \&Pöyhtäri, R. (2017). The assault on journalism: Building knowledge to protect freedom of expression. Nordicom.

Choudhury, P. S. (2011). Media in development communication. Global Media Journal: Indian Edition, 2(2). Constitution of the Federal Republic of Nigeria [Nigeria], Act No. 24, 5 May 1999, available at: https://www.refworld.org/docid/44e344fa4.html [accessed 24 January 2021]

Faisal, A. M., \&Alhassan, A. (2018). Community access and participation in community radio broadcast: Case of Radio Gaakii, Ghana. Journal of Development and Communication Studies, 5(2), 85-102. 
DOI: doi.org/10.47851/naujocommed.v2i1.111

Falade K. I. (2019). On mathematical projection of Nigeria population using numerical techniques https://www.researchgate.net/publication/335830933_ON_MATHEMATICAL_PROJ ECTION_OF_NIGERIA_POPULATION_USING_NUMERICAL_TECHNIQUES Fraser, C., \&Restrepo-Estrada, S. (2002). Community radio for change and development. Development, 45(4), 69-73.

George, M. T., Smith, S. K., Swanson, D. A., \& Tayman, J. (2004). Population projections (pp. 1-128). na.

Harel, A. (2011). Freedom of Speech. COMPANION TO PHILOSOPHY OF LAW, Andrei Marmor, ed, Routledge, Forthcoming.

Human Rights Watch. (2017). Freedom of Expression, Media, and Association. https://www.hrw.org/world-report/2018/country-

Ibukun, Y (2010, September). Nigerian Academics seek to elevate humble Pidgin. Reuters, Lifestyle. Available on http://www.reuters.com/article/2010/09/20/us-nigeria-pidginidUSTRE68J2OG20100920?pageNumber=2

Katunzi, A. (2012). Assessment of community radio in Tanzania: case study of Orkonerei Radio Service FM (Doctoral dissertation).

McCombs, M., \& Reynolds, A. (2002). News influence on our pictures of the world. In Media effects (pp. 11-28). Routledge.

McCombs, M. E., Shaw, D. L., \& Weaver, D. H. (2014). New directions in agenda-setting theory and research. Mass communication and society, 17(6), 781-802.

McQuail, D. (2010). McQuail's mass communication theory. Sage publications.

Mann, C. C. (2000). Reviewing ethnolinguistic vitality: the case of Anglo-Nigerian Pidgin. Journal of Sociolinguistics, 4(3), 458-474.

Mark, M. (2012, September). Nigerian Pidgin dey Scatter my brain yet ginger my swagger. Guardian UK. Available on http://www.guardian.co.uk/world/2012/sep/24/nigeriapidgin-scatter-brain-swagger

Matthes, J. (2008). Need for orientation as a predictor of agenda-setting effects: Causal evidence from a two-wave panel study. International Journal of Public Opinion Research, 20, 440-453.

Mhagama, P. M. (2015). Community radio as a tool for development: A case study of community radio stations in Malawi (Doctoral dissertation, Department of Media and Communication, University of Leicester).

Mohammed, J. (2013). Challenges and Opportunities in the Use of Radio Broadcast for 
DOI: doi.org/10.47851/naujocommed.v2i1.111

ISSN:2756-486X (Online)

Development in Ethiopia: Secondary Data Analysis. Online Journal of Communication and Media Technologies, 3(2), 1.

Motanya, C. C. (2017). Nigerian pidgin: A means of human development. UJAH: Unizik Journal of Arts and Humanities, 18(2), 179-191.

Mtega, W. P. (2018). The Usage of Radio and Television as Agricultural Knowledge Sources: The Case of Farmers in Morogoro Region of Tanzania. International Journal of Education and Development using Information and Communication Technology, 14(3), 252-266.

Ndolo, I. S. (2017). Radio and National Integration in Nigeria. International Journal of Communication: An Interdisciplinary Journal of Communication Studies, 3(1).

Nwagbara, M. O., \& Nwagbara, O. O. (2017). The Role of Radio Stations in Creating Awareness of Climate Change among Crop Farmers in Abia State. The International Journal of Social Sciences and Humanities Invention, 4(4), 397-399

Osoba, J. B. (2014). The use of Nigerian pidgin in media adverts. International Journal of English Linguistics, 4(2), 26.

Rahman Ullah, P., \& Khan, A. U. (2017). Role of FM Radio in Education (A Case Study of FM Radio in Peshawar). J. Soc. Sci, 3(3), 9-16.

Sanni, O. O., \&Ojewale, C. O. (2013). Media influence in awareness creation for government development projects in Lagos State, Nigeria. International Journal of Development and Sustainability. Vol.2. No.2 : 1280-1299

Seidu, A., Andani, A., \& Abdul-Malik, A. (2011). The role of community radio in livelihood improvement: The case of Simli Radio. The Journal of Field Actions, 5.

Shinkhede, C. (2019). Exploring social sustainability of rural community radio: Case of Mann DeshiTarangVahini, Mhaswad, JETIR, Volume 6, Issue 6. Pp. 669-679

Shnukal, A., \&Marchese, L. (1983). Creolization of Nigerian Pidgin English: a progress report. English World-Wide, 4(1), 17-26.

The Research Advisors (2006). Morgan's table for sample size. Available at https://shodhganga.inflibnet.ac.in/bitstream/10603/154745/20/20_appendix\%203.pdf Wazobia FM (2012, May 11). Available on http://www.wazobiafm.com

Weaver, D. H. (2007). Thoughts on agenda setting, framing, and priming. Journal of communication, 57(1), 142-147.

Wihl, G. (2018). Civil Disobedience in Democratic Regimes. Israel Law Review, 51(2), 301320. 